\title{
16. FURTHER COMMENTS ON COCCOLITH STRATIGRAPHY, LEG 12, DEEP SEA DRILLING PROJECT ${ }^{1}$
}

\author{
David Bukry, U. S. Geological Survey, La Jolla, California
}

\section{INTRODUCTION}

Leg 12 of the Deep Sea Drilling Project, June-August 1970, through the North Atlantic Ocean from Boston to Lisbon, recovered 184 cores at nine drilling sites (Figure 1). Light-microscope techniques were used to study the coccoliths of 294 samples from these cores. Zonal assignment of cores from Leg 12 is summarized in Table 1. A discussion of high-latitude coccolith assemblages is followed by a summary of site stratigraphy and by a concluding section where species from selected samples are listed.

Sample numbers for each site consist of elements in the following sequence: cruise-leg number; drill-hole number, composed of site number plus a letter, if more than one hole; core number; core-section number; interval in centimeters below the top of the plastic liner of each core section. For example, 12-117A-3A-2, 117-118 cm, indicates that the sample came from DSDP Leg 12, Hole 117A (at Site 117), the third barrel of core recovered, the second section from the top of that core, and from 117 to 118 centimeters below the top of the section liner. Core sections are 1.5 meters long; most core runs were 9.1 meters long, but some of the core liners are not full. In this report, the tops of incomplete recoveries are arbitrarily placed at the top of core runs, and an approximate depth in meters below the sea floor follows each sample number.

\section{COMPOSITION OF HIGH-LATITUDE COCCOLITH ASSEMBLAGES}

All sites cored by DSDP Leg 12, which range from latitude $45^{\circ} 02^{\prime} \mathrm{N}$ to latitude $59^{\circ} 56^{\prime} \mathrm{N}$, are farther north than any yet attempted by the Deep Sea Drilling Project. The most distinctive feature of high-latitude coccolith assemblages is the paucity of star-shaped discoasters that characterize low-latitude oceanic assemblages. High-latitude assemblages have fewer total species than the low-latitude equivalents and some are numerically dominated by only a few cosmopolitan species that are not ordinarily used as key stratigraphic species at low latitudes. Because of the lack of specialized low-latitude taxa, zonal correlation of high-latitude assemblages commonly must be based on cosmopolitan taxa, usually placoliths, that occur in both high- and low-latitude areas.

Discoaster species that are useful in recognizing zones and subzones throughout essentially all of the Tertiary in tropical areas are generally scarce in post-Eocene samples from Leg 12. As evidence from previous DSDP legs shows discoasters to be among the coccoliths most resistant to

\footnotetext{
${ }^{1}$ Publication authorized by the Director, U. S. Geological Survey.
}

calcite solution, their scarcity here must be mainly a function of paleoecologic exclusion. In Paleocene and Eocene samples, discoasters are present in numbers comparable to more southern samples, but some exclusions exist at the species level, for example, Discoaster tani tani Bramlette and Riedel, a typical member of upper Eocene and lower Oligocene assemblages in the tropics.

A striking reduction in the diversity of high-latitude assemblages is indicated by comparison with equivalent-age assemblages from equatorial oceanic areas. Typical warmwater taxa that are missing from Leg 12 sites or are rarely present include: Bramletteius serraculoides Gartner, Campylosphaera dela (Bramlette and Sullivan), Ceratolithus cristatus Kamptner, C. rugosus Bukry and Bramlette, Discoaster asymmetricus Gartner, D. perplexus Bramlette and Riedel, D. tani tani Bramlette and Riedel, Helicopontosphaera compacta (Bramlette and Wilcoxon), $H$. parallela (Bramlette and Wilcoxon), H. reticulata (Bramlette and Wilcoxon), Oolithotus antillarum (Cohen), Pedinocyclus larvalis (Bukry and Bramlette), Rhabdosphaera clavigera Murray and Blackman, Scyphosphaera globulata Bukry and Percival, S. pulcherrima Deflandre, Sphenolithus abies Deflandre, $S$. dissimilis Bukry and Percival, $S$. neoabies Bukry and Bramlette, $S$. predistentus Bramlette and Wilcoxon, $S$. pseudoradians Bramlette and Wilcoxon, Triquetrorhabdulus carinatus Martini, and $T$. rugosus Bramlette and Wilcoxon.

Some of these taxa, in addition to having flourished in warm-water areas, are among those coccoliths most susceptible to solution. For example, Oolithotus antillarum, Discoaster perplexus, Helicopontosphaera spp. and Scyphosphaera spp. occur commonly in the equatorial Pacific at DSDP Site 62 (latitude $01^{\circ} 52.2^{\prime} \mathrm{N}$, depth 2591 meters), in equivalent-age sediment. Among the more solution-resistant coccoliths are the genera Bramletteius, Campylosphaera, Discoaster, and Triquetrorhabdulus and their rarity in the Leg 12 samples is clearly related to paleoecologic exclusion rather than dissolution.

The absence of some middle and upper Miocene guide fossils, such as Catinaster calyculus Martini and Bramlette, C. coalitus Martini and Bramlette, C. mexicanus Bukry, and Discoaster kugleri Martini and Bramlette, could be merely a result of stratigraphic sampling and not paleoecologic exclusion, as these species mark only short intervals in warmwater cores.

Cosmopolitan taxa that can be used for generalized zonal assignment in post-Eocene areas of both high and low latitude include the following species, for which typical zonal ranges are given: Ceratolithus tricorniculatus [Discoaster quinqueramus Zone to Ceratolithus rugosus Zone], Coccolithus eopelagicus [Chiphragmalithus quadratus Zone to Discoaster exilis Zone], Cyclococcolithina macintyrei 
TABLE 1

Zonal and Geologic Age Assignments of Cores From Deep Sea Drilling Project Leg 12 as Indicated by Coccoliths in Examined Samples

\begin{tabular}{|c|c|c|c|c|c|c|c|c|c|c|c|c|c|}
\hline Age & Zone & $111 \mathrm{~A}$ & 112 & $112 \mathrm{~A}$ & 113 & 114 & 115 & 116 & $116 \mathrm{~A}$ & 117 & $117 \mathrm{~A}$ & 118 & 119 \\
\hline \multirow{3}{*}{ 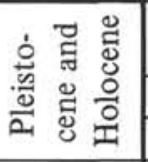 } & Emiliania huxleyi & & & & & & & & \multirow{2}{*}{$1-3 ?$} & & & & \\
\hline & Gephyrocapsa oceanica & & & & 1 & & & & & & & & $1 ?$ \\
\hline & Coccolithus doronicoides & $1-5$ & 1 & 1 & & 1 & & & $4-8$ & & & 2 & 2 \\
\hline \multirow{3}{*}{ 宅 导 } & Discoaster brouweri & 6 & 2 & 3 & $3 ?, 4$ & $2-3 ?$ & & 1 & $8 ?$ & & & 3 & 3 \\
\hline & Reticulofenestra pseudoumbilica & & & 5 & \multirow{5}{*}{$5-11 ?$} & \multirow{8}{*}{$6 ?$} & \multirow{8}{*}{$1 ?$} & \multirow{7}{*}{$6-7 ?$} & & & & $4-5$ & \\
\hline & Ceratolithus rugosus & 6 & & & & & & & & & & & \\
\hline \multirow{10}{*}{$\begin{array}{l}\stackrel{\Xi}{0} \\
\stackrel{0}{\Xi} \\
\Sigma\end{array}$} & Ceratolithus tricorniculatus & & & & & & & & & & & & \multirow{5}{*}{$4 ?$} \\
\hline & Discoaster quinqueramus & 6 & & & & & & & & & & & \\
\hline & Discoaster neohamatus & & 3 & & & & & & & & & & \\
\hline & Discoaster hamatus & & 3 & & & & & & & & & & \\
\hline & Catinaster coalitus & & & & & & & & & & & & \\
\hline & Discoaster exilis & & 4 & & & & & $8-9$ & & & & $6-10$ & 5 \\
\hline & Sphenolithus heteromorphus & & & & & & & $10-11$ & & & & & $6 ?$ \\
\hline & Helicopontosphaera ampliaperta & & & & & & & \multirow{2}{*}{$12 ?$} & & & & & 6 \\
\hline & Sphenolithus belemnos & & & & & & & & & & & & 7 \\
\hline & Triquetrorhabdulus carinatus & & & & & & & $15-19$ & & & & & $8-11$ \\
\hline \multirow{4}{*}{$\begin{array}{l}\text { : } \\
\text { ठ } \\
.00 \\
0\end{array}$} & Sphenolithus ciperoensis & & & & & & & $20-22$ & & 2 & 1 & & $12-13$ \\
\hline & Sphenolithus distentus & & $5 \cdot 11$ & & & & & \multirow{2}{*}{$23-25 ?$} & & & & & $14-15$ \\
\hline & Sphenolithus predistentus & & & & & & & & & & & & $16-17$ \\
\hline & Helicopontosphaera reticulata & & 12 & & & & & 25 & & & & & 18 \\
\hline \multirow{7}{*}{ 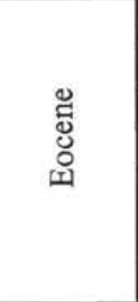 } & Discoaster barbadiensis & & $13-14$ & & & & & $26-28$ & & & & & \\
\hline & Reticulofenestra umbilica & & & & & & & & & & & & \\
\hline & Chiphragmalithus quadratus & & & & & & & & & & & 12 & $19-20$ \\
\hline & Discoaster sublodoensis & $6-8$ & 15 & & & & & & & & & 13 & 21 \\
\hline & Discoaster lodoensis & $8-9$ & & & & & & & & & & 14 & $21-22$ \\
\hline & Tribrachiatus orthostylus & 10 & & & & & & & & & 3 & \multirow{3}{*}{$14-15 ?$} & 23 \\
\hline & Discoaster diastypus & & 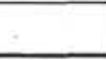 & & & & & & & & 4-8? & & \\
\hline \multirow{5}{*}{ 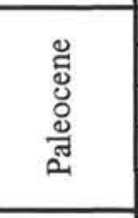 } & Discoaster multiradiatus & & & & & & & & & & & & $25-27$ \\
\hline & Discoaster mohleri & & & & & & & & & & & & $28-30$ \\
\hline & Heliolithus kleinpellii & & & & & & & & & & & & $31-32$ \\
\hline & Cyclolithella robusta & & & & & & & & & & & & $33-36$ \\
\hline & Cruciplacolithus tenuis & & & & & & & & & & & & $36-40$ \\
\hline \multirow{3}{*}{ 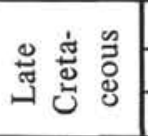 } & Tetralithus murus & & & & & & & & & & & & \\
\hline & Lithraphidites quadratus & 11 & & & & & & & & & & & \\
\hline & Tetralithus gothicus trifidus & 11 & & & & & & & & & & & \\
\hline
\end{tabular}




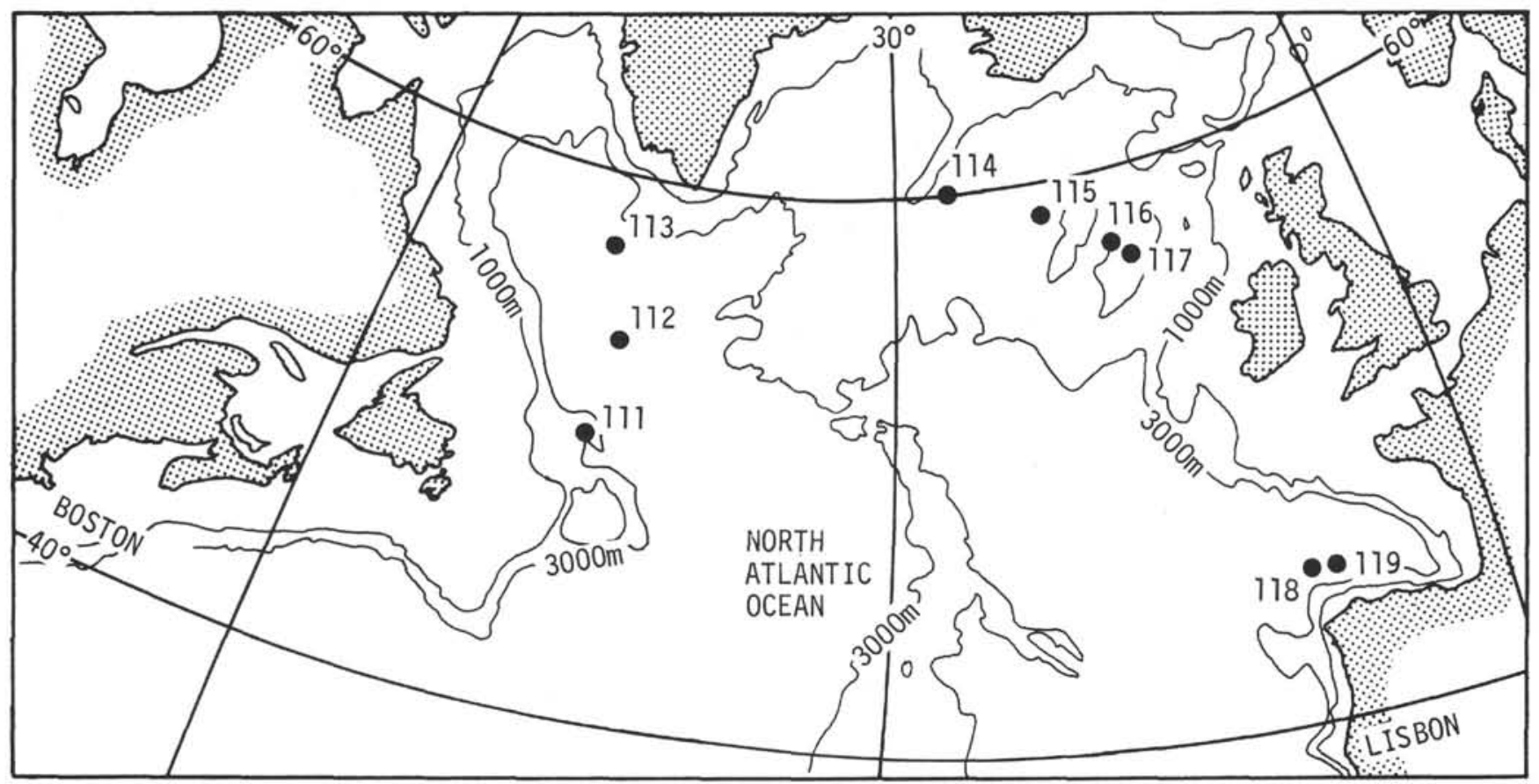

Figure 1. Sites drilled on Leg 12, Deep Sea Drilling Project.

[Sphenolithus heteromorphus Zone to Discoaster brouweri Zone], Cyclococcolithina neogammation [Discoaster barbadiensis Zone to Sphenolithus heteromorphus Zone], Dictyococcites abisectus [Sphenolithus distentus Zone to Triquetrorhabdulus carinatus Zone], Dictyococcites scrippsae [Reticulofenestra umbilica Zone to Sphenolithus ciperoensis Zone], Emiliana annula [Discoaster brouweri Zone to Gephyrocapsa oceanica Zone], Gephyrocapsa oceanica [Gephyrocapsa oceanica Zone to Emiliania huxleyi Zone], Helicopontosphaera kamptneri [Sphenolithus heteromorphus Zone to Emiliania huxleyi Zone], Isthmolithus recurvus [Discoaster barbadiensis Zone to Helicopontosphaera reticulata Zone], Reticulofenestra pseudoumbilica [Sphenolithus heteromorphus Zone to Reticulofenestra pseudoumbilica Zone], Reticulofenestra umbilica [Reticulofenestra umbilica Zone to Helicopontosphaera reticulata Zone].

The only coccolith from Leg 12 that is seemingly restricted to cool-water areas is Coccolithus Neohelis McIntyre and Bé. Originally described from a living North Atlantic population near Bermuda in water at $18.2^{\circ} \mathrm{C}$, it occurs in the upper Pliocene or lower Pleistocene of DSDP Site 113 and DSDP Hole $116 \mathrm{~A}$ (reported on here), and in sediment of the same age in DSDP Site 36 , Leg 5, latitude $40^{\circ} 59^{\prime} \mathrm{N}$ in the eastern Pacific. All other identified taxa are known from low-latitude areas.

Several coccolith assemblages from the Leg 12 cores are unique in being dominated by only one or two species. An upper Oligocene sample from the Hatton-Rockall Basin at Site 117 is essentially an ooze of the two species Zygrhablithus bijugatus Deflandre and Chiasmolithus altus Bukry and Percival. Another group of samples near the PliocenePleistocene boundary in Sites 112, 114 and 116 contains a coccolith ooze dominated by Coccolithus pelagicus (Wallich) and Helicopontosphaera sellii Bukry and Bramlette. Such occurrences are unusual in low-latitude assemblages but may be useful for regional correlation at high latitudes because of short-term duration and ease of identification.

The Leg 12 coccolith assemblages serve to illustrate that a previously recognized discontinuity in Tertiary discoaster populations is accentuated at high latitudes. Discoasters are common and diversified in the upper Paleocene to upper Eocene and in the middle Miocene and upper Miocene. In the Oligocene, at low latitudes, the discoaster diversity is greatly reduced, and this reduction is even more pronounced in the essentially discoaster-barren Oligocene interval of Leg 12. The striking reduction in Discoaster abundance in the high-latitude samples from Leg 12 indicates that reduced ocean-surface temperatures limited Discoaster diversity and abundance. Thus the lowered Oligocene diversity of Discoaster even in tropical areas, is evidence for a mid-Tertiary period of climatic cooling.

\section{SUMMARY OF COCCOLITH STRATIGRAPHY AT LEG 12 SITES}

\section{HOLES 111 AND $111 \mathrm{~A}$}

(lat $50^{\circ} 25.57^{\prime} \mathrm{N}$, long $46^{\circ} 22.05^{\prime} \mathrm{W}$., depth 1811 meters)

This site is on an isolated seamount, "Orphan Knoll", about 560 kilometers northeast of Newfoundland. Coring was carried out to determine if the knoll is a continental remnant, possibly stranded during sea-floor spreading.

Coccolith assemblages of samples available from Hole 111 are sparse. The best assemblage, in Sample 12-111-3-1, 136 to 137 centimeters, contains rare specimens of characteristic Upper Cretaceous species. Sediment from Hole $111 \mathrm{~A}$ ranges in age from Pleistocene to Late Cretaceous. Cores $1 \mathrm{~A}$ to $5 \mathrm{~A}$ (105 to 141 meters) contains sparse early? Pleistocene assemblages characterized by Coccolithus doronicoides, C. pelagicus, Cyclococcolithina leptopora, 
Emiliania annula, and Helicopontosphaera kamptneri. In the absence of Ceratolithus and Scyphosphaera and the rare occurrence of Rhabdosphaera these assemblages are comparable to the cold-water early Pleistocene assemblages of DSDP Leg 5 (eastern Pacific), which are characterized by the same assemblage of poorly diversified placolithid coccoliths (Bukry and Bramlette, 1970).

Pliocene, Miocene and Eocene assemblages are present in Core 6A. Discoasters are rare in the upper Pliocene samples from Sections 1 and 2, which are dominated by placolith forms. A lower Pliocene sample from the bottom of Section 2 (12-111A-6A-2, 146 to 147 centimeters) has a more diverse assemblage, indicating deposition from warmer water. Both upper Miocene and middle Eocene assemblages occur in Section 3.

Several middle and lower Eocene coccoliths zones are present in Cores $6 \mathrm{~A}$ to $10 \mathrm{~A}$. Core $10 \mathrm{~A}$ contains an upper Campanian to lower Maestrichtian coccolith chalk. Common specimens of Braarudosphaera bigelowi, Kamptnerius magnificus, and Lucianorhabdus cayeuxi indicate that the depositional environment of the chalk was comparable to that of Cretaceous chalk of the Gulf Coastal Plain of the United States. This is the first significant occurrence, in a DSDP core, of Kamptnerius which has been used in zonation of shallow oceanic chalk from onshore localities (Bukry, 1969; Cepek and Hay, 1969).

\section{HOLES 112 AND 112A \\ (lat $54^{\circ} 01.00^{\prime} \mathrm{N}$., long $46^{\circ} 36.24^{\prime} \mathrm{W}$., depth 3667 meters)}

Determination of the nature of the sediment section and the age of acoustic reflectors and the basement in the Labrador Sea were the goals at Site 112 .

Coccoliths are common to abundant in most samples examined. Age of the sediment ranges from early Pleistocene (Coccolithus doronicoides Zone) to middle Eocene (Discoaster sublodoensis Zone). The early Pleistocene and late Pliocene assemblages of Cores 1 and 2 (27 to 109 meters) lack the warm-water forms Ceratolithus, Scyphosphaera and Thoracosphaera, and contain Coccolithus pelagicus populations dominated by the variety with a central-area crossbar. Discoaster populations of Core 3, which contains Discoaster hamatus and D. neohamatus, indicate an early late Miocene age. A sample from Core 4 at 203 meters has a poor middle Miocene assemblage belonging to the Discoaster exilis Zone. Cores 5 to 11 (270 to 329 meters) contain middle Oligocene diatom-coccolith ooze with placolith-type coccoliths predominant; discoasters are absent or exceedingly rare. Very diverse lower Oligocene to middle Eocene assemblages of Cores 12 to 15 (384 to 579 meters) contain many solution-etched specimens with ragged outlines.

Redrilling of the site, Hole $112 \mathrm{~A}$, produced a series of poor early Pleistocene or late Pliocene coccolith assemblages in Cores 1A to 4A (79 to 114 meters). Core 5A (122 meters) contains a more diverse coccolith ooze of early Pliocene age.

\section{HOLE 113}

(lat $56^{\circ} 47.40^{\prime} \mathrm{N}$., long $48^{\circ} 19.91^{\prime} \mathrm{W}$., depth 3629 meters)

Site 113 drilled south of the mid-Labrador Sea Ridge, was intended to date the oldest sediments above the basement but had to be abandoned before basement was reached.

Generally poor coccolith assemblages in the 11 cores examined from this site range in age from late Pleistocene to late Miocene or early Pliocene. Most samples contain sparse coccoliths diluted by a silty or sandy matrix. Coccolithus pelagicus and very small coccolith species predominate in the poorly diversified assemblages. Ceratolithus, Rhabdosphaera, Scapholithus and Scyphosphaera are absent, suggesting cool-water deposition of these sediments. Reworked Oligocene and Eocene specimens occur sporadically in the cores.

\section{HOLE 114}

(lat $59^{\circ} 56^{\prime} \mathrm{N}$., long $26^{\circ} 48^{\prime} \mathrm{W}$., depth 1937 meters)

Drilling on the east flank of the Reykjanes Ridge was for the purpose of determining the nature and age of the unusually thick sediment section in the vicinity of Magnetic Anomaly 5 (@10 million years).

Lower Pleistocene (Cores 1 to 3, 100 to 305 meters) and middle Miocene to lower Pliocene (Cores 4 and 6, 400 to 605 meters) coccolith assemblages are present in diatomooze sediment of the upper six cores. Core 1 contrasts with Core 2 by the lack of Coccolithus pelagicus and Helicopontosphaera sellii, species abundant in Core 2. A pelagicussellii ooze also occurs in Hole 112A (Core 3A) near the Pliocene-Pleistocene boundary in the Labrador Sea and in the same stratigraphic position in Site 116 (Core 1) on the Rockall Bank northwest of Ireland. The unusually thick section is mainly a silty clay attributed to contour-current deposition.

\section{HOLE 115}

(lat $58^{\circ} 54.4^{\prime} \mathrm{N}$., long $21^{\circ} 07.0^{\prime} \mathrm{W}$., depth 2893 meters)

Site 115, drilled in the basin between the Reykjanes Ridge and the Rockall Plateau, was chosen to sample and date acoustic reflectors and the acoustic basement. The sediment proved to be alternating hard and soft volcanogenic sandstone, and only small core samples could be recovered.

The single sample available from this site contains rare specimens of long-ranging taxa that indicate the middle Miocene to upper Pliocene, if they are not reworked.

\section{HOLES 116 AND 116A}

(lat $57^{\circ} 29.7^{\prime} \mathrm{N}$., long $15^{\circ} 55.5^{\prime} \mathrm{W}$., depth 1161 meters)

Site 116 was drilled to determine whether the Rockall Plateau, located between Iceland and Ireland, is a continental fragment. The holes are in the Hatton-Rockall Basin, which is on the central part of the Rockall Plateau and contains the thickest sediment. By determining the biostratigraphic and paleoecologic history of the section, it was hoped to determine the tectonic history of the plateau.

A nearly complete sequence of Cenozoic coccolith assemblages, ranging in age from Holocene or late Pleistocene to late Eocene, was cored at this site. The usual warmwater indicators, the discoasters, are common in only a few samples of late early Miocene and middle late Miocene age. The occurrence in lower Pliocene placolith-ooze of Ceratolithus, Rhabdosphaera and Scyphosphaera, along with a few discoasters, also suggests slightly warmer water in this area 
than for coeval deposits of western North Atlantic sites. Eocene assemblages in Cores 26 to 28 ( 826 to 841 meters) are similar to moderately deep oceanic assemblages of other areas in lacking Discolithina, Helicopontosphaera and Rhabdosphaera. The absence of Bramletteius, which occurs elsewhere in both deep and shallow tropical deposits, suggests an upper Eocene oceanic latitudinal temperature gradient, as non-existence due to solution or salinity factors seems to be ruled out. Coring by the D/V Glomar Challenger at still higher latitudes, as proposed by Ewing and Hayes (1970), would provide much-needed additional information on the paleoecology of lower Tertiary coccolith-bearing oceanic nannoplankton, presently considered to be cosmopolitan in distribution.

\section{HOLES 117 AND 117A}

\section{(lat $57^{\circ} 19.5^{\prime} \mathrm{N}$., long $15^{\circ} 23.0^{\prime} \mathrm{W}$., depth 1048 meters)}

Site 117 was drilled near Site 116 in the Hatton-Rockall Basin to supplement the stratigraphic information obtained in Site 116.

Site 117 extends the DSDP 116 section in the HattonRockall Basin with cores in lower Eocene sediment, some of which contain reworked upper Paleocene taxa. The most significant recovery is lower Eocene Tribrachiatus orthostylus Zone sediment of Core 3A ( 222 to 227 meters). This clay with some plant debris and pyrite contains an unusual coccolith assemblage that shows more affinity with lower Eocene assemblages of the London Clay in England and the Rojle Klint in Denmark than with contemporaneous assemblages from oceanic sites (Table 2). The Core $3 \mathrm{~A}$ assemblage is also similar to that of the Lodo Formation of California. Sullivan (1965) interpreted the Lodo Formation to be a littoral marine deposit.

\section{HOLE 118 \\ (lat $45^{\circ} 02.9^{\prime} \mathrm{N}$., long $9^{\circ} 00.5^{\prime} \mathrm{W}$., depth 4901 meters)}

Site 118, in the western part of the Bay of Biscay (Biscay Abyssal Plain), was intended to date prominent acoustic reflectors and the basement in order to provide information about the origin of the Bay of Biscay.

Samples from Cores 2 to 14 (200 to 708 meters) range in age from early Pleistocene to middle Eocene; samples available from the lower part of Core 14 to Core 19 ( 708 to 750 meters) either contain a mixture of late Paleocene and early Eocene specimens, or are barren of coccoliths. Sizesorting and state of preservation are variable through this section. Preservation is generally poor, with solution-etched and broken specimens throughout that typify abyssal-plain turbidite sediments.

\section{HOLE 119}

\section{(lat $45^{\circ} 02.3^{\prime} \mathrm{N}$., long $7^{\circ} 58.8^{\prime} \mathrm{W}$., depth 4447 meters)}

Cantabria Seamount, in the western part of the Bay of Biscay, was drilled to sample pre-Tertiary sediment to supplement the Tertiary section cored at Site 118.

Cores 1 to 40, ranging in age from Pleistocene to early Paleocene, were cut from 10 to 711 meters. Most samples are coccolith ooze. Whereas the preservation state of postOligocene specimens is generally good, the Oligocene and Eocene assemblages show the effects of calcite solution, many specimens having etched margins, missing central structures, and broken rims (Cores 16 to 23 , in particular). Samples from Core 24 are barren.

Exceptionally well-preserved Paleocene assemblages occur with a matrix of calcite particles in Cores 25 to 40 . The preservation state and floral diversity of these Paleocene assemblages are remarkably similar to those described from the Paleocene in the lower part of the Lodo Formation in California (Bramlette and Sullivan, 1961). In Site 119, Heliolithus riedelii Bramlette and Sullivan occurs below and above the first occurrence of Discoaster mohleri Bukry and Percival, but not above the last D. mohleri. Therefore, three upper Paleocene zones are recognized in this hole, based partly on the first occurrences of Heliolithus kleinpellii Sullivan, D. mohleri and Discoaster multiradiatus Bramlette and Riedel, and partly on the ranges of other species, such as Discoasteroides bramlettei Bukry and Percival, Discoaster delicatus Bramlette and Sullivan and Campylosphaera eodela Bukry and Percival (Table 3).

\section{COCCOLITHS IN SELECTED SAMPLES}

\section{HOLE 111}

\section{Cenozoic}

12-111-2-6, 114-116 cm (depth $102 \mathrm{~m}$ ): Coccolithus pelagicus (Wallich), Coccolithus sp. [small] .

\section{Upper Cretaceous}

12-111-3-2, 136-137 cm (depth $191 \mathrm{~m})$ : Apertapetra gronosa (Stover), Biscutum sp., Eiffellithus turisseiffeli (Deflandre), Lithastrinus floralis Stradner, Parhabdolithus embergeri (Noè), Prediscosphaera sp., Watznaueria barnesae (Black), Zygodiscus sp. cf. Z. stenopus (Stover).

\section{HOLE 111A}

\section{Lower Pleistocene \\ (Coccolithus doronicoides Zone)}

12-111A-1A-1, 144-146 cm (depth $106 \mathrm{~m}$ ): Coccolithus pelagicus, Cyclococcolithina leptopora (Murray and Blackman), Emiliania annula (Cohen).

12-111A-3A-1, 141-143 cm (depth $120 \mathrm{~m}$ ):

Coccolithus doronicoides Black and Barnes, C. pelagicus, Cyclococcolithina leptopora, C. macintyrei (Bukry and Bramlette), Discolithina japonica Takayama, Emiliania annula, Helicopontosphaera kamptneri Hay and Mohler, $H$. sellii Bukry and Bramlette, Syracosphaera-sp.

\section{Series Unknown}

12-111A-3A-4, 144-145 cm (depth $125 \mathrm{~m}$ ):

Barren.

12-111A-4A-1, 143-144 cm (depth $126 \mathrm{~m}$ ):

Barren

\section{Lower Pleistocene \\ (Coccolithus doronicoides Zone)}

12-111A-4A-2, 145-146 cm (depth $128 \mathrm{~m}$ ):

Coccolithus doronicoides, C. pelagicus, Emiliania annula, Helicopontosphaera kamptneri. 
TABLE 2

Lower Eocene Tribrachiatus Orthostylus Zone Coccolith Assemblage of

Hole 117A. This Assemblage is More Similar to Shallow-Marine Assemblages Than to an Oceanic Assemblage From The Northwestern Pacific

\begin{tabular}{|c|c|c|c|c|}
\hline $\begin{array}{l}\text { Lower Eocene } \\
\text { Localities }\end{array}$ & 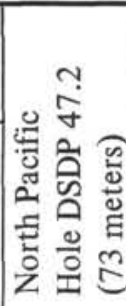 & 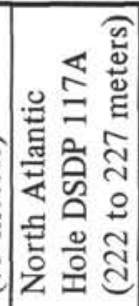 & 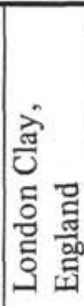 & 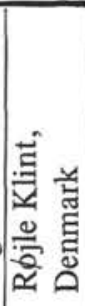 \\
\hline Discoaster binodosus & & $\mathrm{x}$ & $\mathrm{X}$ & $\mathrm{X}$ \\
\hline Lophodolithus nascens & & $\mathrm{X}$ & $\mathrm{X}$ & $\mathrm{X}$ \\
\hline Micrantholithus spp. & & $\mathrm{X}$ & $\mathrm{X}$ & $\mathrm{X}$ \\
\hline Syracosphaera cf. S. fimbriata & & $\mathrm{X}$ & $\mathrm{X}$ & $\mathrm{X}$ \\
\hline Zygolithus dubius & & $\mathrm{X}$ & $\mathrm{X}$ & $\mathrm{X}$ \\
\hline Zygolithus protenus & & $\mathrm{X}$ & $\mathrm{X}$ & $\mathrm{X}$ \\
\hline Chipragmalithus calathus & & $\mathrm{X}$ & $\mathrm{X}$ & \\
\hline Discoaster? obscurus & & $\mathrm{X}$ & & $\mathrm{X}$ \\
\hline Discoaster? aff. D? obscurus & & $\mathrm{X}$ & $\mathrm{X}$ & \\
\hline Discolithina ocellata & & $\mathrm{X}$ & $\mathrm{X}$ & \\
\hline Transversopontis pulcher & & $\mathrm{X}$ & & $\mathrm{X}$ \\
\hline Transversopontis pulcheroides & & $\mathrm{X}$ & $\mathrm{X}$ & \\
\hline Discoasteroides kuepperi & $\mathrm{X}$ & $\mathrm{X}$ & $\mathrm{X}$ & $\mathrm{X}$ \\
\hline Tribrachiatus orthostylus & $\mathrm{X}$ & $\mathrm{X}$ & $\mathrm{X}$ & $\mathrm{X}$ \\
\hline Zygrhablithus cf. Z. bijugatus & $\mathrm{X}$ & $\mathrm{X}$ & $\mathrm{X}$ & \\
\hline Coccolithus crassus & $\mathrm{X}$ & $\mathrm{X}$ & $\mathrm{X}$ & \\
\hline Discoaster barbadiensis & $\mathrm{X}$ & $\mathrm{X}$ & & $\mathrm{X}$ \\
\hline Discoaster lodoensis & $\mathrm{X}$ & & & $\mathrm{X}$ \\
\hline Chiasmolithus grandis & $\mathrm{X}$ & $\mathrm{X}$ & & \\
\hline Markalius inversus & $\mathrm{X}$ & $\mathrm{X}$ & & \\
\hline Sphenolithus radians & $\mathrm{X}$ & $\mathrm{X}$ & & \\
\hline Campylosphaera dela & $\mathrm{X}$ & & & \\
\hline Cyclolithella bramlettei & $\mathrm{X}$ & & & \\
\hline
\end{tabular}

12-111A-5A-1, 142-143 cm (depth $135 \mathrm{~m}$ ):

Coccolithus doronicoides, C. pelagicus, Cyclococcolithina leptopora, Rhabdosphaera clavigera Murray and Blackman.

\section{Upper Pliocene \\ (Discoaster brouweri Zone)}

12-111A-6A-1, 141-142 cm (depth $144 \mathrm{~m}$ ):

Coccolithus doronicoides, C. pelagicus, Cyclococcolithina leptopora, C. macintyrei, Discoaster sp. cf. D. brouweri Tan, Discoaster sp. aff. D. exilis Martini and Bramlette [webbed rays].
12-111A-6A-2, 38-39 cm (depth $144 \mathrm{~m}$ ):

Ceratolithus rugosus Bukry and Bramlette, Coccolithus pelagicus, Cyclococcolithina leptopora, C. macintyrei, Discoaster pentaradiatus Tan, D. surculus Martini and Bramlette, Discolithina sp.

\section{Lower Pliocene (Ceratolithus rugosus Zone)}

12-111A-6A-2, 146-147 cm (depth $145 \mathrm{~m}$ ):

Ceratolithus rugosus, C. tricorniculatus Gartner, Coccolithus pelagicus [abundant], Cyclococcolithina leptopora, 
TABLE 3

Occurrence of Selected Upper Paleocene Coccoliths in Representative Samples From North Atlantic DSDP Site 119 Compared With South Atlantic DSDP Site 21, Northwestern Pacific DSDP Site 47.2, Pont Labau in France (Hay and Mohler, 1967), Lodo Formation in California (Bramlette and Sullivan, 1961)

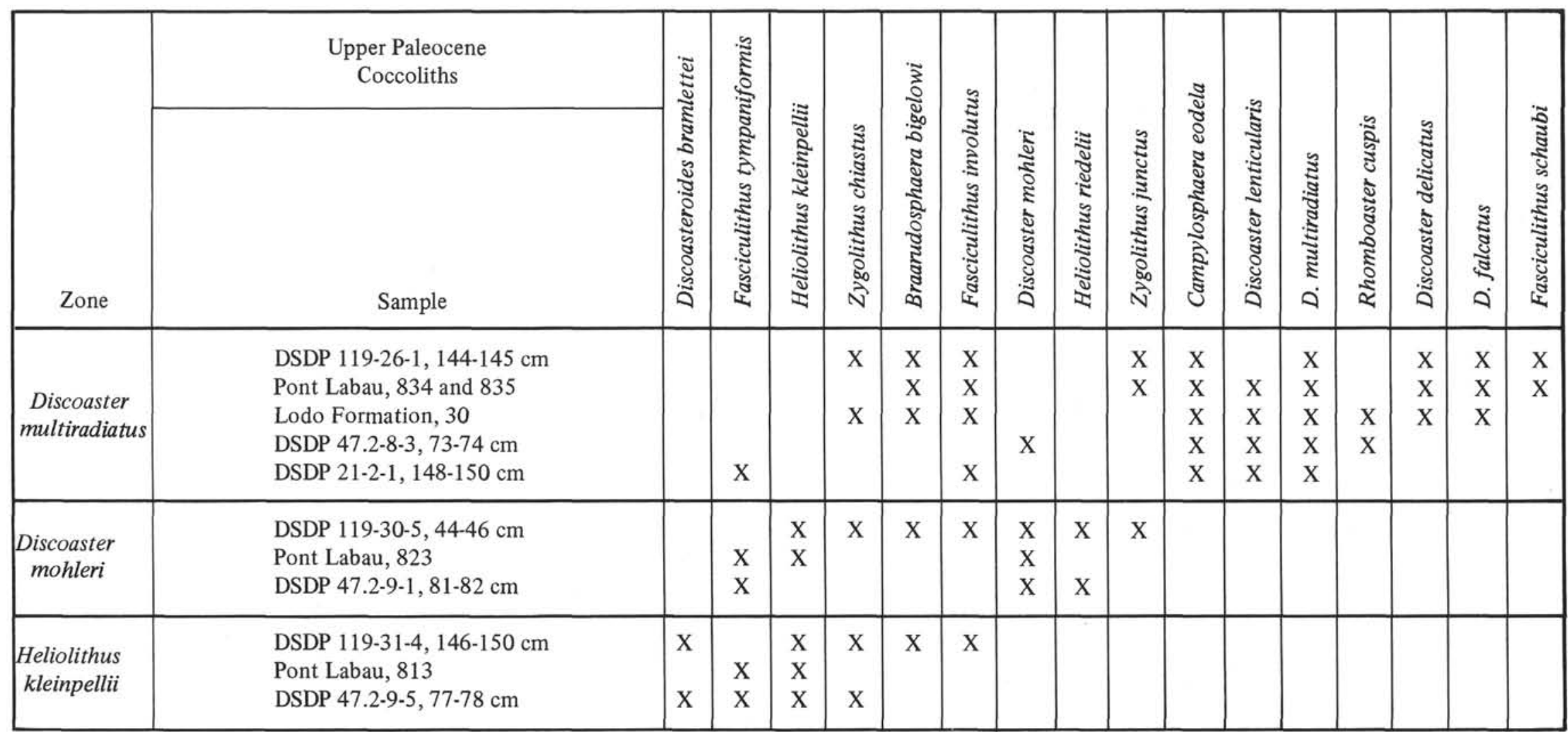


C. macintyrei, Discoaster brouweri, D. pentaradiatus, Discoaster sp. cf. D. surculus, D. variabilis variabilis Martini and Bramlette, Discolithina japonica, D. multipora (Kamptner ex Deflandre) s. l., Helicopontosphaera kamptneri, $H$. sellii, Reticulofenestra pseudoumbilica (Gartner), Rhabdosphaera sp. cf. $R$. procera Martini, Scyphosphaera intermedia Deflandre, Sphenolithus neoabies Bukry and Bramlette.

\section{Upper Miocene \\ (Discoaster quinqueramus Zone)}

12-111 A-6A-3, 74-75 cm (depth $146 \mathrm{~m}$ ):

Ceratolithus tricorniculatus [rare], Coccolithus pelagicus, Cyclococcolithus leptopora, C. macintyrei, Discoaster berggrenii Bukry, D. braarudii Bukry, D. brouweri s. L, D. pentaradiatus, D. quinqueramus Gartner, D. surculus, D. variabilis variabilis, Helicopontosphaera granulata Bukry and Percival, $H$. kamptneri, Reticulofenestra pseudoumbilica.

\section{Middle Eocene \\ (Discoaster sublodoensis Zone)}

12-111A-6A-3, 135-136 cm (depth $147 \mathrm{~m}$ ): Campylosphaera dela (Bramlette and Sullivan), Chiasmolithus grandis (Bramlette and Riedel), Cyclococcolithina formosa (Kamptner), Cyclolithella bramlettei (Hay and Towe), Discoaster barbadiensis Tan, D. distinctus Martini, D. lodoensis Bramlette and Riedel, D. sublodoensis Bramlette and Sullivan, D. wemmelensis Acuthan and Stradner, Reticulofenestra samodurovi (Hay, Mohler, and Wade).

\section{Lower Eocene \\ (Discoaster lodoensis Zone)}

12-111A-8A-2, 143-144 cm (depth $164 \mathrm{~m}$ ):

Campylosphaera dela, Chiasmolithus grandis, $C$. solitus Bramlette and Sullivan, Coccolithus crassus Bramlette and Sullivan, Cyclolithella bramlettei, Discoaster cruciformis Martini, D. elegans Bramlette and Sullivan, D. lodoensis, D. nonaradiatus Klumpp, Discoasteroides kuepperi Stradner, Ellipsolithus lajollaensis Bukry and Percival, Helicopontosphaera sp. cf. $H$. lophota (Bramlette and Sullivan), $H$. seminulum (Bramlette and Sullivan), Lophodolithus mochlophorus Deflandre, L. nascens Bramlette and Sullivan, Reticulofenestra sp. aff. $R$. umbilica [structurally similar species, but two zones lower than typical first occurrence]. Rhabdosphaera sp. cf. $R$. perlonga (Deflandre), Sphenolithus radians Deflandre, Syracopshaera fimbriata (Bramlette and Sullivan), Syracosphaera sp., Transversopontis pulcheroides (Sullivan), Zygolithus dubius Deflandre.

\section{Lower Eocene}

(Tribrachiatus orthostylus Zone)

12-111A-10A-1, 146-147 cm (depth $174 \mathrm{~m}$ ): Campylosphaera dela, Chiasmolithus grandis, Cyclolithella bramlettei, Discoaster elegans, D. lodoensis, Discoasteroides kuepperi, Discolithina plana Bramlette and Sullivan, Helicopontosphaera seminulum, Lophodolithus nascens, Syracosphaera fimbriata, Transversopontis pulcher (Deflandre), Tribrachiatus orthostylus Shamrai [non. subst. pro Discoaster tribrachiatus Bramlette and Riedel] Zygolithus dubius.
Upper Cretaceous [Maestrichtian]

(Lithraphidites quadratus Zone)

12-111A-11A-4, 143-144 cm (depth $187 \mathrm{~m}$ ):

Apertapetra gronosa, Arkhangelskiella cymbiformis Vekshina, Biscutum testudinarium Black and Barnes, Braarudosphaera bigelowi (Gran and Braarud), Cretarhabdus conicus Bramlette and Martini, C. crenulatus Bramlette and Martini, Cribrosphaera ehrenbergii Arkhangelsky, Cylindralithus gallicus Bramlette and Martini, Eiffellithus turriseiffeli, Kamptnerius magnificus Deflandre, Lithraphidites quadratus Bramlette and Martini, Lucianorhabdus cayeuxi Deflandre, Marthasterites inconspicuus Deflandre, Microrhabdulus decoratus Deflandre, $M$. stradneri Bramlette and Martini, Micula decussata Vekshina, Prediscosphaera cretacea cretacea (Arkhangelsky), P. cretacea lata Bukry, P. spinosus Bramlette and Martini, Watznaueria barnesae.

\section{Upper Cretaceous [Campanian] \\ (Tetralithus gothicus trifidus Zone)}

12-111A-11A-6, 138-139 cm (depth $190 \mathrm{~m}$ ):

Arkhangelskiella cymbiformis, Biscutum testudinarium, Broinsonia parca (Stradner), Cretarhabdus crenulatus, Cribrosphaera ehrenbergii, Cylindralithus gallicus, Eiffellithus turriseiffeli, Kamptnerius magnificus, Microrhabdulus decoratus, Micula decussata, Prediscosphaera cretacea cretacea, Tetralithus aculeus (Stradner), T. gothicus trifidus Stradner and Papp, Watznaueria barnesae, Zygodiscus meudini Bukry.

\section{HOLE 112}

\section{Lower Pleistocene \\ (Coccolithus doronicoides Zone)}

12-112-1-1, 147-148 cm (depth $28 \mathrm{~m}$ ):

Coccolithus pelagicus, Cyclococcolithina leptopora, $C$. macintyrei, Gephyrocapsa caribbeanica Boudreaux and Hay, Helicopontosphaera kamptneri, H. sellii, Rhabdosphaera clavigera, Scapholithus sp.

\section{Upper Pliocene \\ (Discoaster brouweri Zone)}

12-112-2-2, 142-143 cm (depth $103 \mathrm{~m}$ ):

Coccolithus pelagicus, Cyclococcolithina leptopora, C. macintyrei, Discoaster brouweri, Discolithina japonica, Emiliania annula, Helicopontosphaera kamptneri, H. sellii, Rhabdosphaera clavigera, Syracosphaera sp.

\section{Upper Miocene \\ (Discoaster neohamatus Zone)}

12-112-3-3, 142-143 cm (depth $153 \mathrm{~m}$ ):

Cyclococcolithina leptopora, C. macintyrei, Discoaster bellus Bukry and Percival, D. bollii Martini and Bramlette, D. braaruddi, D. brouweri s. l., D. calcaris Gartner, D. neohamatus Bukry and Bramlette, D. obtusus Gartner, D. prepentaradiatus Bukry and Percival, D. variabilis variabilis, Reticulofenestra pseudoumbilica, Sphenolithus neoabies, Triquetrorhabdulus rugosus Bramlette and Wilcoxon.

\section{Upper Miocene \\ (Discoaster hamatus Zone)}

12-112-3-6, 129-131 cm (depth $158 \mathrm{~m}$ ):

Cyclococcolithina leptopora, Discoaster bellus, D. 
braarudii $D$. hamatus Martini and Bramlette, $D$. variabilis variabilis, $R$. pseudoumbilica, Triquetrorhabdulus rugosus.

Middle Miocene

(Discoaster exilis Zone)

12-112-4-2, 138-139 cm (depth $203 \mathrm{~m}$ ):

Braarudosphaera bigelowi [rare, transported?], Coccolithus eopelagicus (Bramlette and Riedel), Cyclococcolithina leptopora, Discoaster deflandrei Bramlette and Riedel, $D$. exilis, $D$. variabilis variabilis, Reticulofenestra pseudoumbilica, Triquetrorhabdulus rugosus.

\section{Middle Oligocene \\ (Sphenolithus distentus Zone)}

12-112-5-1, 136-137 cm (depth $271 \mathrm{~m}$ ):

Chiasmolithus altus Bukry and Percival, Coccolithus eopelagicus, Cyclococcolithina neogammation (Bramlette and Wilcoxon), Dictyococcites abisectus (Müller), D. bisectus (Hay, Mohler and Wade), D. scrippsae Bukry and Percival, Discoaster deflandrei [5-and 6-rayed], Reticulofenestra gartneri Roth and Hay, Sphenolithus moriformis (Brönnimann and Stradner).

12-112-11-4, 144-145 cm (depth $329 \mathrm{~m}$ ):

Cyclococcolithina neogammation, Dictyococcites bisectus, Reticulofenestra gartneri.

\section{Lower Oligocene \\ (lower Helicopontosphaera reticulata Zone)}

12-112-12-1, 141-142 cm (depth $385 \mathrm{~m}$ ):

Chiasmolithus altus, C. oamaruensis (Deflandre), Coccolithus eopelagicus, Dictyococcites bisectus, D. scrippsae, Discoaster tani nodifer Bramlette and Riedel, Helicopontosphaera sp. cf. $H$. intermedia Martini, $H$. reticulata Bramlette and Wilcoxon, Isthmolithus recurvus Deflandre, Polycladolithus sp., Reticulofenestra hillae Bukry and Percival, $R$. insignita Roth and Hay, R. umbilica (Levin), ?Rhabdosphaera tenuis Bramlette and Sullivan [stems], R. spinula Levin and Joerger, Sphenolithus moriformis [small], Transversopontis ponticulus (Deflandre).

\section{Upper Eocene \\ (Discoaster barbadiensis Zone)}

12-112-13-2, 138-140 cm (depth $443 \mathrm{~m}$ ):

Chiasmolithus oamaruensis, Coccolithus eopelagicus, Cyclococcolithina neogammation, Cyclococcolithina sp. cf. C. reticulata (Gartner and Smith), Dictyococcites bisectus, D. scrippsae, Discoaster barbadiensis, D. saipanensis Bramlette and Riedel, Isthmolithus recurvus, Pontosphaera vadosa Hay, Mohler and Wade, Reticulofenestra hillae, R. umbilica, Transversopontis pulcheroides.

12-112-14-2, 142-144 cm (depth $499 \mathrm{~m}$ ):

Campylosphaera dela [rare], Chiasmolithus sp. cf. C. expansus, Coccolithus eopelagicus, $C$. fenestratus (Deflandre), Cyclococcolithina formosa (Kamptner), C. neogammation, C. sp. cf. C. reticulata, Dictyococcites bisectus, D. scrippsae, Discoaster barbadiensis, D. distinctus, D. saipanensis, Goniolithus fluckigeri Deflandre, Helicopontosphaera compacta (Bramlette and Wilcoxon), $H$. sp. cf. $H$. intermedia, ?Isthmolithus recurvus, Markalius inversus (Deflandre), Micrantholithus stradneri Chang, Reticulofenestra samodurovi, R. umbilica, Rhabdosphaera spinula,
?R. tenuis [stems], Sphenolithus predistentus Bramlette and Wilcoxon, Transversopontis pulcher, T. pulcheroides, Zygolithus dubius.

\section{Middle Eocene \\ (Discoaster sublodoensis Zone)}

12-112-15-1, $47-48 \mathrm{~cm}$ (depth $578 \mathrm{~m}$ ):

Chiasmolithus expansus, C. solitus, Coccolithus pseudogammation Bouché, C. staurion Bramlette and Sullivan, Cyclococcolithina formosa, C. luminis (Sullivan), Discoaster barbadiensis, $D$. nonaradiatus Klumpp, $D$. saipanensis, $D$. sublodoensis Bramlette and Sullivan, Rhabdosphaera inflata Bramlette and Sullivan, Transversopontis pulcher, Zygolithus dubius, Zygrhablithus bijugatus Deflandre.

\section{HOLE 112A}

\section{Lower Pleistocene}

(Coccolithus doronicoides Zone)

12-112A-1A-1, 144-145 cm (depth $79 \mathrm{~m}$ ):

Coccolithus doronicoides, C. pelagicus, Cyclococcolithina leptopora, C. macintyrei, Discolithina japonica, Emiliania annula, Helicopontosphaera kamptneri, H. sellii.

\section{Upper Pliocene \\ (Discoaster brouweri Zone)}

12-112A-3A-1, 140-141 cm (depth $98 \mathrm{~m}$ ):

Coccolithus doronicoides, C. pelagicus, Cyclococcolithina leptopora, C. macintyrei, Discoaster brouweri [rare], Discolithina japonica, Emiliania annula, Helicopontosphaera sellii.

\section{Lower Pliocene \\ (Reticulofenestra pseudoumbilica Zone)}

12-112A-5A-5, 139-140 cm (depth $122 \mathrm{~m}$ ):

Ceratolithus rugosus, Coccolithus pelagicus, Coccolithus sp. [tiny], Cyclococcolithina leptopora, C. macintyrei, Discoaster brouweri, $D$. challengeri Bramlette and Riedel, $D$. pentaradiatus, $D$. surculus, D. variabilis pansus Bukry and Percival, Helicopontosphaera kamptneri, Reticulofenestra pseudoumbilica, Rhabdosphaera procera Martini, Sphenolithus abies.

\section{HOLE 113}

\section{Upper Pleistocene \\ (Gephyrocapsa oceanica Zone)}

12-113-1-1, 145-146 cm (depth $50 \mathrm{~m}$ ):

Coccolithus pelagicus, Coccolithus sp. [tiny], Gephyrocapsa sp. cf. G. caribbeanica, G. oceanica Kamptner, Syracosphaera sp. Reworked Eocene or Oligocene taxa: Dictyococcites scrippsae, Reticulofenestra hillae.

\section{Upper Pliocene(?)}

12-113-3-3, 141-142 cm (depth $159 \mathrm{~m}$ ):

Coccolithus pelagicus, Coccolithus sp. cf. C. neohelis McIntyre, Cyclococcolithina macintyrei [well-preserved].

\section{Upper Pliocene}

(Discoaster brouweri Zone)

12-113-4-2, 114-115 cm (depth $206 \mathrm{~m}$ ):

Coccolithus pelagicus, Cyclococcolithina macintyrei, 
Discoaster brouweri, Discoaster sp. cf. D. variabilis variabilis.

Upper Miocene or Lower Pliocene

12-113-5-1, 144-145 cm (depth $254 \mathrm{~m})$ :

$12-113-8-4,13-15 \mathrm{~cm}$ (depth $667 \mathrm{~m})$ :

12-113-9-3, 6-9 cm (depth $712 \mathrm{~m}$ ):

12-113-11-2, 100-110 cm (depth $811 \mathrm{~m})$ :

These above samples contain rare specimens of long-ranging coccoliths. The most common taxa are Coccolithus pelagicus, Cyclococcolithina leptopora, C. macintyrei and Reticulofenestra pseudoumbilica; also present are Discoaster fragments assigned to $D$. pentaradiatus and $D$. surculus.

HOLE 114

Lower Pleistocene

(Coccolithus doronicoides Zone)

12-114-1-5, $81 \mathrm{~cm}$ (depth $107 \mathrm{~m}$ ):

Cyclococcolithina leptopora, Discolithina sp. cf. D. japonica, Emiliania annula, Gephyrocapsa caribbeanica, Helicopontosphaera kamptneri.

\section{Upper Pliocene or Lower Pleistocene}

(Transitional)

12-114-2-6, 128-130 cm (depth $209 \mathrm{~m}$ ):

Coccolithus pelagicus [abundant], Cyclococcolithina leptopora, C. macintyrei, Discolithina sp., Helicopontosphaera sellii [abundant].

12-114-3-5, 103-104 cm (depth $305 \mathrm{~m})$ :

Coccolithus doronicoides, C. pelagicus, Coccolithus sp. [tiny], Cyclococcolithina leptopora, C. macintyrei, Discolithina sp. cf. D. japonica, D. multipora, Helicopontosphaera kamptneri, H. sellii, Scyphosphaera sp. Reworked Oligocene taxon: Chiasmolithus altus.

\section{HOLE 115}

\section{Middle Miocene to Upper Pliocene}

12-115-1-1, 63-64 cm (depth $59 \mathrm{~m}$ ):

Coccolithus sp. [small], Cyclococcolithina macintyrei, Discolithina japonica, Helicopontosphaera kamptneri, Reticulofenestra sp. cf. R. pseudoumbilica [small].

\section{HOLE 116}

\section{Upper Pliocene \\ (Discoaster brouweri Zone)}

12-116-1-6, 140-141 cm (depth $79 \mathrm{~m}$ ):

Coccolithus doronicoides, C. pelagicus [abundant], Coccolithus sp. [tiny], Cyclococcolithina leptopora, C. macintyrei, Discoaster brouweri, D. variabilis variabilis, Helicopontosphaera sellii [common], Scyphosphaera apsteinii Lohmann, Syracosphaera pulchra Lohmann.

\section{Middle Miocene}

(Sphenolithus heteromorphus Zone)

\section{2-116-10-6, 139-140 cm (depth $518 \mathrm{~m}$ ):}

Coccolithus eopelagicus, Cyclococcolithina neogammation, Discoaster sp. cf. D. deflandrei, D. sp. cf. D. exilis, Discolithina segmenta Bukry and Percival,
Helicopontosphaera granulata Bukry and Percival, $H$. sp. cf. H. kamptneri, Sphenolithus heteromorphus Deflandre.

\section{Lower Miocene \\ (Triquetrorhabdulus carinatus Zone)}

12-116-18-4, 140-141 cm (depth $695 \mathrm{~m}$ ):

Coccolithus pelagicus [abundant], Cyclococcolithina neogammation, Dictyococcites abisectus, D. scrippsae, Discoaster deflandrei, Discolithina sp., Helicopontosphaera parallela (Bramlette and Wilcoxon), Sphenolithus moriformis, Triquetrorhabdulus sp. cf. T. carinatus Martini, Zygrhablithus bijugatus [abundant].

\section{Upper Oligocene \\ (Sphenolithus ciperoensis Zone)}

12-116-21-4, 140-141 cm (depth $716 \mathrm{~m}$ ):

Chiasmolithus altus, Coccolithus fenestratus, C. pelagicus, Cyclococcolithina neogammation, Dictyococcites abisectus, D. bisectus, D. scrippsae, Discoaster deflandrei, Discolithina segmenta, Reticulofenestra gartneri, Sphenolithus moriformis, Zygrhablithus bijugatus [abundant].

\section{Lower Oligocene \\ (Helicopontosphaera reticulata Zone)}

12-116-25-5, 141-142 cm (depth $812 \mathrm{~m}$ ):

Chiasmolithus oamaruensis, Coccolithus fenestratus, C. pelagicus, Cyclococcolithina formosa, Dictyococcites bisectus, $D$. scrippsae, Discoaster tani nodifer, Isthmolithus recurvus, Pontosphaera vadosa, Reticulofenestra hillae, $R$. umbilica, Zygrhablithus bijugatus.

\section{Upper Eocene \\ (Discoaster barbadiensis Zone)}

12-116-26-1, 66-67 cm (depth $826 \mathrm{~m}$ ):

Coccolithus eopelagicus, Cyclococcolithina formosa, C. neogammation, $C$. sp. cf. C. reticulata, Dictyococcites bisectus, $D$. scrippsae, Discoaster sp cf. D. tani nodifer, $D$. saipanensis, Isthmolithus recurvus, Lanternithus minutus Stradner, Pontosphaera vadosa, Reticulofenestra hillae, $R$. umbilica, Zygrhablithus bijugatus.

12-116-28-1, 90-91 cm (depth $840 \mathrm{~m}$ ):

Chiasmolithus sp. cf. C. expansus, C. oamaruensis, Coccolithus pelagicus, Cyclococcolithina formosa, $C$. sp. cf. $C$. reticulata [small], Dictyococcites bisectus, D. scrippsae, Discoaster saipanensis, Reticulofenestra umbilica, Zygrhablithus bijugatus.

\section{HOLE 116A}

\section{Upper Pleistocene or Holocene}

12-116A-1A-2, 133-134 cm (depth $2 \mathrm{~m}$ ): Coccolithus pelagicus, Cyclococcolithina leptopora, ?Emiliania huxleyi Kamptner, ?Gephyrocapsa ericsonii McIntyre and Bé, Helicopontosphaera kamptneri, Syracosphaera sp. cf. S. histrica.

\section{Lower Pleistocene}

(Coccolithus doronicoides Zone)

12-116A-4A-6, 140-141 cm (depth $35 \mathrm{~m}$ ):

Coccolithus doronicoides, C. pelagicus, Cyclococcolithina leptopora, C. macintyrei, Discolithina japonica, D. 
multipora s. l., Emiliania annula, Gephyrocapsa caribbeanica, Helicopontosphaera kamptneri, Scyphosphaera sp., Syracosphaera histrica.

12-116A-7A-2, 140-141 cm (depth $56 \mathrm{~m}$ ):

Coccolithus neohelis, C. pelagicus, Cyclococcolithina leptopora, C. macintyrei, Helicopontosphaera sellii, Rhabdosphaera clavigera, Syracosphaera sp.

12-116A-8A-3, 141-142 cm (depth $66 \mathrm{~m}$ ):

Acanthoica sp. aff. A. acanthos Schiller, Coccolithus doronicoides, $C$. pelagicus, Cyclococcolithina leptopora, $C$. macintyrei, Helicopontosphaera sellii, Rhabdosphaera sp. cf. R. stylifera Lohmann, Syracosphaera sp.

\section{Upper Pliocene(?)}

12-116A-8A-4, 147-148 cm (depth $68 \mathrm{~m}$ ):

Coccolithus pelagicus, Cyclococcolithina leptopora, C. macintyrei, Discoaster sp. cf. D. brouweri [rare], Discolithina japonica, Emiliania annula, Helicopontosphaera kamptneri [rare].

\section{HOLE 117}

\section{Upper Oligocene \\ (Sphenolithus ciperoensis Zone)}

12-117-2-3, 146-148 cm (depth $102 \mathrm{~m}$ ):

Braarudosphaera discula Bramlette and Riedel [rare], Chiasmolithus altus [fantastically abundant], Coccolithus eopelagicus, Cyclococcolithina neogammation, Dictyococcites abisectus, D. bisectus, D. scrippsae, Discoaster deflandrei, Sphenolithus moriformis, Zygrhablithus bijugatus [abundant].

12-117-2-4, 144-145 cm (depth $103 \mathrm{~m}$ ):

Chiasmolithus altus, Coccolithus eopelagicus, Cyclococcolithina neogammation, Dictyococcites abisectus, D. bisectus, D. scrippsae, Discoaster deflandrei, Discolithina sp., Reticulofenestra gartneri, Sphenolithus ciperoensis, S. moriformis, Zygrhablithus bijugatus.

\section{HOLE 117A}

\section{Upper Oligocene}

(Sphenolithus ciperoensis Zone)

12-117A-1A-1, 54-55 cm (depth $147 \mathrm{~m}$ ):

Chiasmolithus altus, Coccolithus eopelagicus, Cyclococcolithina neogammation, Dictyococcites bisectus, D. scrippsae, Helicopontosphaera truncata (Bramlette and Wilcoxon), Zygrhablithus bijugatus.

12-117A-1A-1, 70-71 cm (depth $147 \mathrm{~m}$ ):

Chiasmolithus altus, Cyclococcolithina neogammation, Reticulofenestra gartneri. Reworked Lower Eocene taxa: Discoaster lodoensis, D. sp. aff. D. obscurus Martini, Discoasteroides kuepperi, Tribrachiatus orthostylus.

\section{Lower Eocene \\ (Tribrachiatus orthostylus Zone)}

12-117A-3A-1, 131-132 cm (depth $222 \mathrm{~m}$ ):, Chiasmolithus grandis, Coccolithus crassus, Cyclococcolithina luminis. Discoaster binodosus, Markalius inversus, Micrantholithus sp., Syracosphaera fimbriata, Transversopontis pulcheroides, Tribrachiatus orthostylus, Zygolithus dubius, Zygrhablithus bijugatus.
12-117A-3A-4, 137-138 cm (depth $226 \mathrm{~m})$ :

Chiphragmalithus calathus Bramlette and Sullivan, Discoaster obscurus, D. sp. aff. D. obscurus, Discoasteroides kuepperi, Lophodolithus nascens, Syracosphaera fimbriata, Tribrachiatus orthostylus, Zygolithus dubius, Zygrhablithus bijugatus.

12-117A-3A-6, 140-141 cm (depth $229 \mathrm{~m}$ ):

Discolithina ocellata (Bramlette and Sullivan), Micrantholithus sp., Syracosphaera fimbriata, Transversopontis pulcher, T. pulcheroides, Zygolithus dubius, Z. protenus (Bramlette and Sullivan).

\section{Upper Paleocene or Lower Eocene}

12-117A-4A-1, 136-137 cm (depth $271 \mathrm{~m}$ ):

Braarudosphaera bigelowi, Chiasmolithus bidens (Bramlette and Sullivan), Discoaster multiradiatus Bramlette and Riedel, D. ornatus Stradner, Ellipsolithus distichus (Bramlette and Sullivan), Zygolithus chiastus Bramlette and Sullivan, Z. dubius, Z. junctus Bramlette and Sullivan.

12-117A-6A-1, 144-145 cm (depth $276 \mathrm{~m}$ ):

Braarudosphaera bigelowi, Chiasmolithus bidens, Discoaster sp. cf. D. diastypus Bramlette and Sullivan, Discolithina ocellata, Ellipsolithus macellus Bramlette and Sullivan, Markalius inversus, Transversopontis pulcheroides, Tribrachiatus contortus (Stradner), [basionym: Discoaster contortus Stradner, 1958, Erdoel-Z. 74: p. 187, Figures 35-36], Tribrachiatus orthostylus, Zygrhablithus bijugatus.

\section{HOLE 118}

\section{Lower Pleistocene \\ (Coccolithus doronicoides Zone)}

12-118-2-6, 147-148 cm (depth $209 \mathrm{~m}$ ):

Coccolithus doronicoides, C. pelagicus, Cyclococcolithina leptopora, C. macintyrei, Discolithina japonica, D. multipora s. l., Gephyrocapsa caribbeanica, Helicopontosphaera kamptneri, H. sellii, Rhabdosphaera clavigera, Scapholithus sp.

\section{Upper Pliocene \\ (Discoaster brouweri Zone)}

12-118-3-2, 149-150 cm (depth $303 \mathrm{~m}$ ):

Coccolithus doronicoides, C. pelagicus, Cyclococcolithina leptopora, C. macintyrei, Discoaster brouweri s. l. [rare].

\section{Upper Miocene \\ (Ceratolithus tricorniculatus Zone)}

12-118-4-3, 147-148 cm (depth $354 \mathrm{~m}$ ):

Ceratolithus tricorniculatus, Cyclococcolithina leptopora, C. macintyrei, Discoaster brouweri s. l., D. pentaradiatus, D. sp. cf. D. variabilis variabilis, Helicopontosphaera kamptneri, Reticulofenestra pseudoumbilica.

\section{Middle Miocene (Discoaster exilis Zone)}

12-118-6-1, 144-145 cm (depth $449 \mathrm{~m}$ ):

Coccolithus eopelagicus, Cyclococcolithina leptopora, C. macintyrei, Discoaster sp. cf. D. aulokos Gartner, D. braarudii, $D$. challengeri, $D$. deflandre, $D$. exilis, $D$. variabilis variabilis. Helicopontosphaera kamptneri, Lithostromation perdurum Deflandre, Reticulofenestra 
pseudoumbilica, Triquetrorhabdulus rugosus. Reworked Eocene taxon: Discoaster saipanensis.

12-118-8-1, 92-93 cm (depth $506 \mathrm{~m}$ ):

Coccolithus eopelagicus, Cyclococcolithina macintyrei, Discoaster braarudii, D. challengeri, $D$. sp. cf. D. dilatus Hay, $D$. sp. cf. D. exilis, D. variabilis variabilis, Discolithina multipora s. l., Reticulofenestra pseudoumbilica. Reworked Miocene taxon: Sphenolithus heteromorphus.

12-118-10-1, 111-112 cm (depth $605 \mathrm{~m}$ ):

Coccolithus eopelagicus, Cyclococcolithina leptopora, Discoaster braarudii, D. deflandrei, D. exilis, Reticulofenestra pseudoumbilica, Sphenolithus neoabies, Triquetrorhabdulus rugosus.

\section{Series unknown}

12-118-11-1, 28-29 cm (depth $650 \mathrm{~m}$ ):

Barren.

12-118-12-1, 0-5 cm (depth $687 \mathrm{~m})$ :

Barren.

12-118-12-2, 71-74 cm (depth $688 \mathrm{~m})$ :

Barren.

Middle Eocene

(Chiphragmalithus quadratus Zone)

12-118-12-4, 141-142 cm (depth $692 \mathrm{~m}$ ):

Campylosphaera dela, Chiasmolithus expansus, C. gigas (Bramlette and Sullivan), C. grandis, C. solitus [small], Ciphragmalithus cristatus (Martini), C. quadratus Bramlette and Sullivan, Coccolithus pseudogammation, C. staurion Bramlette and Sullivan, Cyclococcolithina formosa, Discoaster barbadiensis, D. gemmeus Stradner, D. saipanensis, D. wemmelensis.

\section{Middle Eocene \\ (Discoaster sublodoensis Zone)}

12-118-13-2, 148-150 cm (depth $696 \mathrm{~m}$ ):

Chiasmolithus sp. cf. C. expansus, C. solitus, Chiphragmalithus cristatus, Coccolithus pseudogammation, C. staurion, Cyclococcolithina formosa, Discoaster barbadiensis, $D$. sp. cf. D. lodoensis, D. sp. cf. D. sublodoensis, Triquetrorhabdulus inversus Bukry and Bramlette.

Lower Eocene

(Discoaster lodoensis Zone)

12-118-14-1, 140-141 cm (depth 696 to $708 \mathrm{~m}$ ):

Chiasmolithus grandis, Coccolithus crassus, Cyclococcolithina formosa, Discoaster barbadiensis, D. lodoensis [large, abundant], D. stradneri Noë1,Discoasteroides kuepperi [rare], Tribrachiatus orthostylus [rare].

\section{Mixed Upper Paleocene and Lower Eocene}

12-118-14-2, 132-134 cm (depth 696 to $708 \mathrm{~m}$ ):

Eocene taxa: Chiasmolithus grandis, Coccolithus crassus, Discoaster barbadiensis, D. diastypus, Tribrachiatus orthostylus. Paleocene taxa: Campylosphaera eodela Bukry and Percival, Discoaster multiradiatus, D. ornatus. Eocene and Paleocene taxa: Chiasmolithus consuetus, Ellipsolithus macellus.

12-118-15-1, 99-100 cm (depth $714 \mathrm{~m}$ ):

Paleocene taxa: Campylosphaera eodela, Chiasmolithus bidens, Discoaster lenticularis Bramlette and Sullivan, D. multiradiatus, D. ornatus, Rhomboaster cuspis Bramlette and Sullivan, Toweius eminens Bramlette and Sullivan. Eocene or Paleocene taxa: Chiasmolithus consuetus, ?Tribrachiatus contortus.

Series unknown

12-118-16-1, 52-53 cm (depth $723 \mathrm{~m})$ :

Barren.

12-118-17-1, 143-144 cm (depth $732 \mathrm{~m}$ ):

Barren.

12-118-19-1, 8-9 cm (depth $750 \mathrm{~m})$ :

Barren.

\section{HOLE 119}

\section{Upper Pleistocene}

12-119-1-2, 143-144 cm (depth $12 \mathrm{~m}$ ):

Coccolithus pelagicus, Cyclococcolithina leptopora, Gephyrocapsa spp., Helicopontosphaera kamptneri. Reworked Uppre Cretaceous taxa: Chiastozygus disgregatus (Stover), Cretarhabdus crenulatus, Prediscosphaera cretacea cretacea.

\section{Middle Miocene \\ (Discoaster exilis Zone)}

12-119-5-1, 132-133 cm (depth $199 \mathrm{~m}$ ):

Coccolithus eopelagicus, Cyclococcolithina leptopora, Discoaster exilis, Discoaster subsurculus Gartner, Helicopontosphaera granulata, $H$. kamptneri, Reticulofenestra pseudoumbilica, Sphenolithus neoabies, Triquetrorhabdulus rugosus.

\section{Middle Oligocene \\ (Sphenolithus distentus Zone)}

12-119-14-5, 148-150 cm (depth $318 \mathrm{~m}$ ):

Chiasmolithus altus, Coccolithus eopelagicus, C. fenestratus, Cyclococcolithina neogammation, Dictyococcites abisectus, D. bisectus, D. scrippsae, Discoaster deflandrei, Reticulofenestra gartneri, Sphenolithus distentus (Martini), S. moriformis, $S$. predistentus. Reworked Cretaceous taxon: Cretarhabdus crenulatus.

\section{Lower Oligocene \\ (Helicopontosphaera reticulata Zone)}

12-119-18-3, 142-143 cm (depth $353 \mathrm{~m}$ ):

Chiasmolithus altus, C. oamaruensis, Coccolithus eopelagicus, C. fenestratus, Cyclococcolithina neogammation, Dictyococcites bisectus, D. scrippsae, Discoaster deflandrei, D. tani nodifer, D. tani tani Bramlette and Riedel, Helicopontosphaera compacta, Isthmolithus recurvus, Reticulofenestra hillae, $R$. umbilica, ?Rhabdosphaera tenuis [stems].

\section{Middle Eocene \\ (Chiphragmalithus quadratus Zone)}

12-119-19-1, 140-141 cm (depth $357 \mathrm{~m}$ ):

Campylosphaera dela, Chiasmolithus gigas, C. grandis, Chiphragmalithus mexicanus (Stradner), C. sp. cf. $C$. spinosus (Stradner), Cyclococcolithina formosa, Discoaster barbadiensis, D. martinii Stradner, D. saipanensis, 
D. tani nodifer, D. wemmelensis, Reticulofenestra samodurovi.

\section{Middle Eocene \\ (Discoaster sublodoensis Zone)}

12-119-21-1, 143-144 cm (depth $375 \mathrm{~m}$ ):

Chiasmolithus grandis, Chiphragmalithus cristatus, Coccolithus pseudogammation, C. staurion, Discoaster barbadiensis, D. mirus Deflandre, D. sublodoensis, D. wemmelensis, Rhabdosphaera inflata, Sphenolithus radians, Triquetrorhabdulus inversus.

\section{Lower Eocene \\ (Discoaster lodoensis Zone)}

12-119-214, 149-150 cm (depth $380 \mathrm{~m}$ ):

Coccolithus sp. [rim fragments resulting from solution], Discoaster barbadiensis, $D$. lodoensis, $D$. nonaradiatus, $D$. septemradiatus (Klumpp), Discoasteroides kuepperi.

Lower Eocene

(Tribrachiatus orthostylus Zone)

12-119-23-1, 141-142 cm (depth $392 \mathrm{~m}$ ):

Coccolithus sp. [rare rim fragment], Discoaster barbadiensis, D. lodoensis, D. nonaradiatus [rare], Discoasteroides kuepperi, Tribrachiatus orthostylus [abundant, late variety] .

\section{Series unknown}

12-119-24-1, 21-22 cm (depth $401 \mathrm{~m})$ :

Barren.

12-119-24-2, 139-140 cm (depth $402 \mathrm{~m}$ ):

Barren.

12-119-24-3, 94-95 cm (depth $402 \mathrm{~m}$ ):

Barren.

\section{Upper Paleocene \\ (Discoaster multiradiatus Zone)}

12-119-26-1, 144-145 cm (depth $420 \mathrm{~m}$ ):

Braarudosphaera bigelowi, Campylosphaera eodela, Chiasmolithus bidens, C. californicus (Sullivan), C. consuetus, Discoaster delicatus Bramlette and Sullivan, D. falcatus Bramlette and Sullivan, D. helianthus Bramlette and Sullivan, D. limbatus Bramlette and Sullivan, D. multiradiatus, Discolithina plana, D. solida (Deflandre), Ellipsolithus distichus, Fasciculithus involutus Bramlette and Sullivan, F. schaubi Hay and Mohler, Scapholithus apertus Hay and Mohler, Toweius eminens, Zygodiscus plectopons Bramlette and Sullivan, Z, sigmoides Bramlette and Sullivan, Zygolithus chiastus Bramlette and Sullivan, $Z$. distentus Bramlette and Sullivan, Z. junctus Bramlette and Sullivan, Zygrhablithus bijugatus, Z. simplex Bramlette and Sullivan. The preservation and diversity of this assemblage matches that of the lower Lodo Formation in California (Bramlette and Sullivan, 1961). Reworked Upper Cretaceous taxa: Arkhangelskiella cymbiformis, Prediscosphaera cretacea cretacea, Zygodiscus deflandrei Bukry.

\section{Upper Paleocene \\ (Discoaster mohleri Zone)}

12-119-30-6, 63-64 cm (depth $500 \mathrm{~m}$ ):

Braarudosphaera bigelowi, Chiasmolithus bidens, $C$. californicus, C. consuetus, Coccolithus pelagicus s. l., Discoaster mohleri Bukry and Percival, Discoasteroides megastypus Bramlette and Sullivan, Ellipsolithus distichus, E. macellus, Fasciculithus tympaniformis, Heliolithus kleinpellii, $H$. riedelii Bramlette and Sullivan, Scapholithus apertus, Toweius eminens, Zygodiscus plectopons, Zygolithus chiastus. Reworked Upper Cretaceous taxa: Broinsonia parca, Watznaueria barnesae.

\section{Upper Paleocene \\ (Heliolithus kleinpellii Zone)}

12-119-31-1, 104-108 cm (depth $544 \mathrm{~m}$ ):

Chiasmolithus sp. cf. C. bidens, $C$. consuetus, Cruciplacolithus tenuis (Stradner), Cyclolithella sp. cf. C. robusta (Bramlette and Sullivan), Ellipsolithus macellus, Fasciculithus involutus, $F$. tympaniformis, Heliolithus kleinpellii, $H$. riedelii [rare], Toweius eminens, Zygodiscus sp. aff. $Z$. plectopons Bramlette and Sullivan, Z. sigmoides, Zygolithus chiastus. Reworked Upper Cretaceous taxa: Broinsonia parca, Micula decussata, Watznaueria barnesae.

Lower Paleocene

(Cruciplacolithus tenuis Zone)

12-119-40-4, 51-56 cm (depth $704 \mathrm{~m})$ :

Braarudosphaera bigelowi, Coccolithus pelagicus s. l., Cruciplacolithus tenuis, Ericsonia? subpertusa Hay and Mohler, Zygodiscus sigmoides. Reworked Upper Cretaceous taxa: Prediscosphaera cretacea cretacea, Watznaueria barnesae.

\section{ACKNOWLEDGMENT}

I wish to thank M. N. Bramlette, Scripps Institution of Oceanography, for providing reference samples from European localities and for discussions on the correlation of lower Cenozoic coccolith assemblages.

\section{REFERENCES}

Bramlette, M. N. and Sullivan, F. R., 1961. Coccolithophorids and related nannoplankton of the early Tertiary in California. Micropaleontology. 7, 129.

Bukry, D., 1969. Upper Cretaceous coccoliths from Texas and Europe. Kansas Univ. Paleont. Contr. 51, 1.

Bukry, D. and Bramlette, M. N., 1970. Coccolith age determinations Leg 5, Deep Sea Drilling Project. In McManus, D. A. et al., 1970. Initial Reports of the Deep Sea Drilling Project, Volume V. Washington (U.S. Government Printing Office) 487.

Cepek, P. and Hay, W. W., 1969. Calcareous nannoplankton and biostratigraphic subdivision of the Upper Cretaceous. Trans. Gulf Coast Assoc. Geol. Soc. 19, 323.

Ewing, M. and Hayes, D., 1970. Deep-sea drilling in Antarctic waters. Geotimes. 15, 15.

Hay, W. W. and Mohler, H. P., 1967. Calcareous nannoplankton from early Tertiary rocks at Pont Labau, France, and Paleocene-early Eocene correlations. $J$. Paleontology. 41, 1505.

Sullivan, F. R., 1965. Lower Tertiary nannoplankt on from the California Coast Ranges-Pt. 2, Eocene. California Univ. Pubs. Geol. Sci. 53, 1 . 